\title{
UNA APROXIMACIÓN A LA CULTURA VISUAL DE LA FIESTA BARROCA. LOS RETRATOS DE PRESENCIAS VIRTUALES
}

\author{
AN APPROACH TOWARDS THE VISUAL CULTURE OF THE BAROQUE \\ FESTIVAL. PORTRAITS OF VIRTUAL PRESENCES
}

\section{Gorka López de Munain \\ Universidad de Barcelona}

ABSTRACT: In this study I deal briefly with some issues related to the visual culture of the Baroque festival; and more specifically, with those related to the royal portraits that were on display during the festive activities. To this end I place special emphasis on developing the concepts of presence, body and virtuality -as applied to those works or visual objects- from an approach that offers a new theoretical framework, namely, that which involves «image studies» or "visual culture studies» (Bildwissenschaft, Bildanthropologie y visual studies). dies.

KEYWORDS: Baroque Festival, Royal Portraits, Presence, Body, Virtuality, Image Stu-

RESUMEN: En el presente estudio abordaremos brevemente algunas cuestiones relativas a la cultura visual de la fiesta barroca; y más específicamente, aquellas vinculadas a los retratos reales que se exponían durante los actos festivos. Para ello, pondremos especial énfasis en desarrollar los conceptos de presencia, cuerpo y virtualidad -aplicados a dichas obras u objetos visuales-, desde un marco teórico novedoso como es el determinado por los estudios de la imagen o estudios de cultura visual (Bildwissenschaft, Bildanthropologie y visual studies).

PALABRAS CLAVES: fiesta barroca, retratos reales, presencia, cuerpo, virtualidad, estudios de la imagen. 
El retrato está hecho para guardar la imagen en ausencia de la persona, se trate de un alejamiento o de la muerte. El retrato es la presencia del ausente, una presencia in absentia que está encargada no sólo de reproducir los rasgos, sino de presentar la presencia en tanto ausente: de evocarla (y hasta invocarla), y también de exponer, de manifestar, el retiro en el que esa presencia se mantiene (Nancy, 2006: 53).

La finalidad de este trabajo no es otra que reflexionar sobre un problema que atraviesa de forma transversal la larga y compleja historia de la representación icónica: el valor de la presencia; en nuestro caso, aplicada a la representación de los monarcas. A lo largo de este recorrido aparecerá en multitud de ocasiones el viejo problema/fantasma: ¿Por qué no estamos sólo ante un cuadro o una escultura? Si bien es cierto que la intensidad de estas presencias (siempre variables, matizadas) adquirió una dimensión verdaderamente poderosa en los siglos del barroco, desde luego el fenómeno que analizaremos está muy lejos de pertenecerle en exclusiva. La idea de que las imágenes están habitadas por una presencia se remonta aguas arriba a los orígenes mismos de la humanidad y, desde luego, no entiende de fronteras, culturas, ni épocas. Este poder de presencia de las imágenes lo tenemos perfectamente interiorizado y nos valemos de su capacidad retórica en situaciones y contextos muy variados. Por ejemplo, yéndonos a un caso curioso de representación de la realeza, el ayuntamiento navarro de Villava colgó en uno de sus plenos, por obligación de UPN, una fotocopia del rey pegada con celo [fig. 1]. Es obvio que los miembros del ayuntamiento gobernado por Bildu, no demasiado conformes con la figura del monarca, buscaron el modo de que su presencia en aquel acto fuera la mínima posible.

Observaremos algunos ejemplos de representación de la realeza dentro de la llamada

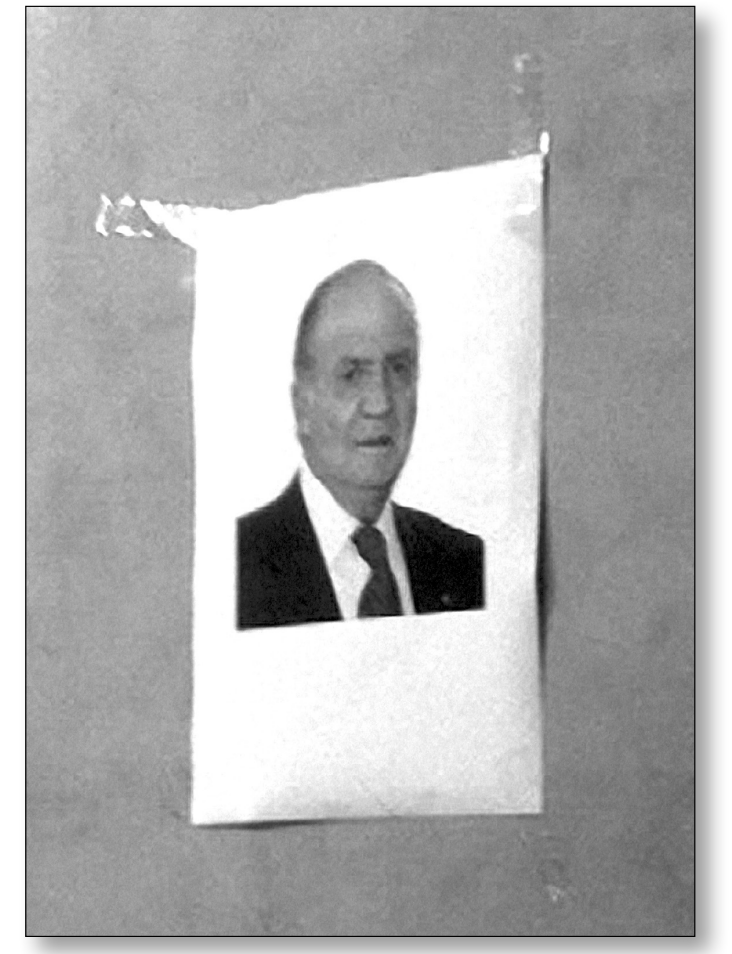

Fig. 1. Fotocopia de la imagen del Rey pegada con celo en el pleno del Ayuntamiento navarro de Villava. 2011.

fiesta barroca, con especial atención a los actos acontecidos con motivo de la exaltación al trono de Fernando VI. Como es de sobra conocido, la fiesta pública ha sido habitual objeto de análisis para quienes se dedican al estudio de la emblemática, pues en tales representaciones y escenificaciones abundan gran parte de los elementos principales que constituyen esta disciplina. Estos actos demostraron ser un eficaz aparato de propaganda y persuasión capaz de cohesionar el imperio y de asegurar la lealtad de las élites dirigentes (Mínguez, 2009). Sin embargo, nuestro estudio discurrirá por otros derroteros, empleando los textos e imágenes que ilustran estos acontecimientos a modo de excusa para estructurar el discurso que buscamos construir en torno a la teoría del retrato y sus rasgos de virtualidad en el ámbito festivo. Las imágenes que utilizaremos serán de naturaleza diversa, por lo que habrá que detenerse en su teori- 


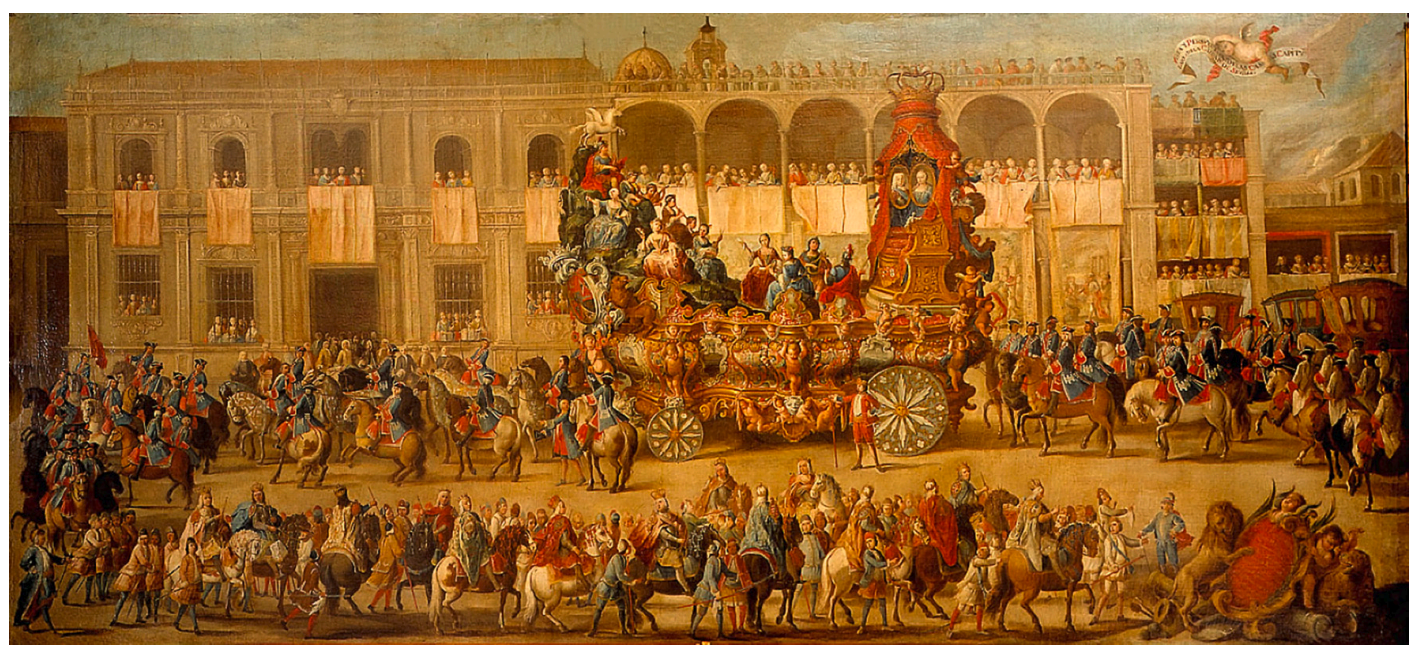

Fig. 2. El Carro del Parnaso, Domingo Martínez, Sevilla, 1748.

zación a fin de no caer en lecturas erróneas o desenfocadas. Según Hans Belting, y aplicando una lectura de corte más antropológico, una imagen «es más que un producto de la percepción. Se manifiesta como resultado de una simbolización personal o colectiva» (Belting, 2010: 14). Atendiendo a esta idea, comprobamos que algunas imágenes presentan diferentes capas de significación. En el caso de los lienzos de Domingo Martínez, elaborados con motivo de la Máscara organizada por la Real Fábrica de Tabacos en Sevilla para celebrar la exaltación al trono de Fernando VI [fig. 2], los estratos se suceden configurando un complejo entramado visual. Por una parte, las obras recogen los actos festivos constituyendo en sí mismas una imagen para la memoria y el recuerdo de unos fastos de gran solemnidad. Pero, también, muestran el proceso de recepción y simbolización de otra imagen no menos importante: la de los retratos de Fernando VI y Bárbara de Braganza que viajan en el carro del Parnaso [fig. 3]. Estas imágenes sustituyen a los personajes reales adoptando las actitudes y acciones propias de

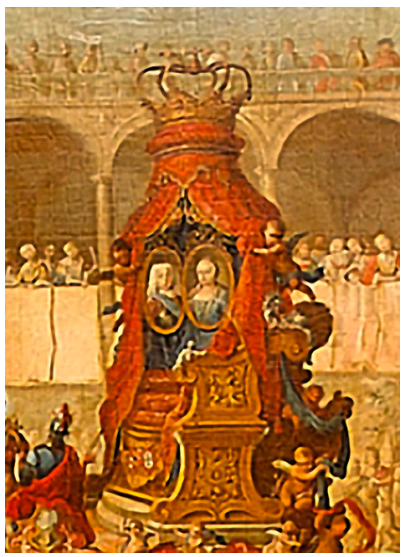

Fig. 3. El Carro del Parnaso, Domingo Martínez, Sevilla, 1748. Detalle de los retratos de Fernando VI y Bárbara de Braganza que viajan en el carro.

sus referentes. En un primer momento puede sorprender este uso pseudomágico de las imágenes, pero, como veremos más adelante, éste no es sino un pequeño ejemplo de una realidad en la que la línea que separa la «representación" de la "presentación» es sumamente delgada. ${ }^{1}$

1. Para completar este análisis resultaría fundamental incorporar la idea de «medio», que tan agudamente desarrolló Hans Belting en su obra Antropología de la imagen, 2010. Aunque en este trabajo, por motivos de espacio principalmente, no se ha incorporado este concepto, en futuros acercamientos trataremos de dar una visión más amplia añadiendo el marco teórico ofrecido por Belting.

IMAGO, NÚM. 5, 2013, 7-17 
A pesar de que en un principio pueda parecer un acercamiento excesivamente tangencial, creemos que es pertinente dar salida a este tipo de estudios como complemento a todos aquellos que, por habituales, comienzan a perder fecundidad y capacidad de generar nuevos conocimientos. Desde luego el lienzo de El Carro del Parnaso de Martínez que aquí presentamos encajaría a la perfección en un análisis iconográfico e iconológico clásico, dada la cantidad de elementos susceptibles de interpretación que muestra, pero creemos que las claves para dichos estudios están notablemente atendidas, no ocurriendo lo mismo con nuestra propuesta metodológica. En general los aspectos teóricos de estas y otras creaciones visuales han sido y siguen siendo ampliamente debatidos en los círculos académicos (y críticos), pero se echa de menos una mayor aplicación "práctica» de los mismos a la realidad de las obras del pasado (desde un diálogo permanente con nuestro presente).

En los trabajos sobre emblemática, los estudios de la cultura visual (o si se prefiere visual studies ${ }^{2}$ ) están llamados a generar nuevos enfoques que ayuden a seguir dando pasos sobre los ya aportados por nuestros maestros y compañeros. Precisamente el estudio de los emblemas, o en este caso un pequeño detalle de un cuadro, encaja perfectamente dentro del nuevo campo extendido de objetos visuales a los que están prestando atención estas nuevas corrientes (inter/trans-disciplinares), los cuales, como ha demostrado Brea, entre otros, no presentan necesariamente un verdadero diferencial epistemológico comparados con las llamadas obras maestras (Brea, 2006). Pero, por otro lado, Mieke Bal incide en que el "objeto de los estudios de la cultura visual puede ser mejor definido no en términos de los objetos que incluye sino partiendo de su función» (Bal, 2004: 22). Para justificarlo, Bal pone como ejemplo el trabajo de Louis Marin sobre los usos estratégicos del retratos de Luis XIV en la Francia del siglo XVII (Marin, 1981), lo cual viene a confirmar que este camino emprendido puede ser provechoso y, sobre todo, muy fecundo.

La implantación efectiva de estas propuestas en los ámbitos académicos españoles es, hasta la fecha, menor de lo que sería deseable, pero paulatinamente se advierte un cierto interés que invita a ser optimistas. ${ }^{3}$ Bajo estas premisas metodológicas intentaremos ahondar en el modo en que funcionaban ciertos retratos durante estas celebraciones y, también, cómo eran éstos percibidos por los asistentes a los festejos. Los nexos con nuestro presente serán inevitables, pues, aunque pueda parecer una comparación fuera de lugar, no es tan grande la distancia que separa la exhibición en carruajes de los retratos reales con motivo de su reciente exaltación al trono, de la retransmisión en las pantallas gigantes de Times Square en Nueva York de la boda de los príncipes de Inglaterra [fig. 4]. En ambos casos la imagen que está siendo el objeto de todas las miradas tiene muchos rasgos de virtualidad, pero expone unas características de actualidad que precisan ser estudiadas con atención. Cambian los medios, pero los gestos, las intenciones, sobreviven. ${ }^{4}$

Hablamos de un acontecimiento público, que en ciertos aspectos deviene casi sagrado, enlazando muy estrechamente con

2. A modo de introducción (y advertencia) a la problemática terminológica que rodea los estudios de la imagen, W. J. T. Mitchell comenta que «es útil distinguir entre 'estudios visuales' y 'cultura visual', el primero el campo de estudio y el segundo su objeto, su objetivo. Estudios visuales es así el estudio de la cultura visual. Esta aclaración evita la ambigüedad que infesta materias como la de la 'historia', en la cual el campo y las cosas abarcadas por el mismo reciben el mismo nombre» (Mitchell, 2003: 18).

3. Un buen ejemplo de este camino adoptado son las recientes publicaciones de Fernando Rodríguez de la Flor entre las que podemos destacar: Imago. La cultura visual y figurativa del barroco, 2009.

4. Para ampliar la idea de supervivencia de las imágenes, resulta indispensable consultar la obra de Georges DidiHuberman, La imagen superviviente, 2009. 


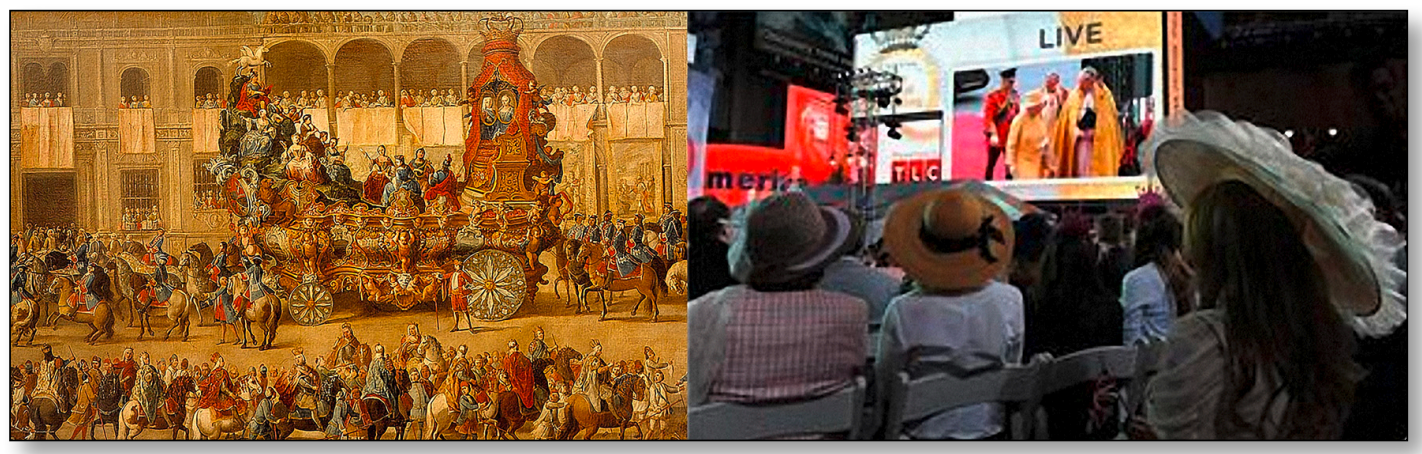

Fig. 4. Montaje entre la obra de Domingo Martínez y una fotografía de la agencia EFE que muestra a un grupo de neoyorkinos siguiendo la boda real de los príncipes de Inglaterra en Times Square

la distinción entre lo «visible» y lo «visual» acontecida propiamente en el ámbito de la imaginería medieval. Lo visible era el ídolo del Éxodo (XX, 4), la imagen de la venustas (la visibilidad de lo visible), mientras lo visual pertenecía al ámbito de lo sagrado, al de la verdad encarnada o figurada. ${ }^{5}$ Los retratos que analizaremos desde un punto de vista teórico, están muy cerca del dominio de lo visual y en cierta medida alejados del propiamente visible. Todo el aparato exaltatorio que rodea a las imágenes reales contribuye, como veremos, a construir el valor o componente visual que dota a la obra de unas características que podríamos calificar, en sentido benjaminiano, de auráticas. Parafraseando a Didi-Huberman, lo que perseguimos con este trabajo es en el fondo muy simple: en un cuadro de pintura figurativa, "algo representa» y "algo se ve»-pero algo, de todas formas, se muestra también, se mira, nos mira-. Siendo todo el problema, claro está, el cernir la economía de ese "de todas formas" y de pensar en el estatus de ese "algo" (Didi-Huberman, 2010a: 205).

\section{LOS RETRATOS EN LAS FIESTAS BARROCAS. LA EXALTACIÓN AL TRONO DE FERNANDO VI}

Al hablar de retratos, y sobre todo de su poder para evocar una presencia, a todos nos puede venir a la memoria la famosa expresión de la Lógica de Port-Royal «el retrato de César es César», ${ }^{6}$ o la no menos conocida Regis imago, Rex est, ideas que sin duda trascienden en mucho su aparente simpleza. No nos debe sorprender este modo de percibir las imágenes, pues eran famosas aquellas que incluso se decía que hablaban, tal y como atestiguan gran cantidad de documentos y crónicas (Corteguera, 2009: 5368 ). De igual modo, la creencia en el poder de las imágenes gozaba de una salud férrea, a pesar de que la iglesia tratara de frenar sin ningún éxito estas prácticas supersticiosas (Freedberg, 2009).

Son innumerables los ejemplos en los que se pone de manifiesto un uso de la imagen y una recepción de la misma, que conecta de modo singular con los retratos de

5. Estas ideas están ampliadas en: Didi-Huberman, 2010a: 40-43. Es pertinente recordar la crítica que le historiador del arte francés hace a la tradición historiográfica: «La historia del arte no logra comprender la inmensa constelación de los objetos creados por el hombre con vistas a una eficacia de lo visual, cuando busca integrarlos en el esquema acordado del dominio de lo visible. Así, ignoró demasiado a menudo la consistencia antropológica de las imágenes medievales». (Didi-Huberman, 2010a: 43).

6. Para un estudio más detenido de la Lógica de Port-Royal aplicada al estudio de los retratos reales ver: Marin, 1975. Un comentario detallado de la citada frase lo encontramos en: Marin, 1981: 209 y sig. También podemos leer unas interesantes observaciones en: Didi-Huberman, 2008: 71 y sig.

IMAGO, NÚM. 5, 2013, 7-17 
ámbito festivo que posteriormente analizaremos. Ya Bazin nos recuerda que el propio Luis XIV no se hizo embalsamar, puesto que estaba contento con sobrevivir en el retrato que le había realizado Charles Le Brun (Bazin, 1967: 10). Y el ejemplo no es anecdótico, pues los procesos de embalsamamiento llevados a cabo desde la Edad Media en algunas cortes europeas (especialmente en Francia e Inglaterra) presentaban unas características propias que merece la pena apuntar. El recurso a estas efigies era en un principio debido a que las ceremonias funerarias se extendían mucho en el tiempo y el cuerpo acababa pudriéndose, lo que obligó a que se construyeran este tipo de figuras sustitutivas. Atendiendo a la teoría de los dos cuerpos del rey de Kantorovicz, el cuerpo natural era el depositado en el féretro, mientras que el cuerpo político era expuesto mediante su efigie (su medio portador) con todos los atributos reales (KantorowiCz, 1985: 392 y sig.). Tal fue el desarrollo de estas prácticas que la efigie llegó a jugar un papel determinante y activo en las ceremonias fúnebres muy por encima del que recibía el verdadero cuerpo difunto del rey. ${ }^{7}$

\section{$* * *$}

Comenzamos este breve repaso a la fiesta de exaltación de Fernando VI con las celebraciones organizadas en la ciudad hispalense. Estos festejos duraban varios días y en ellos se programaban numerosas activi- dades. Como en este caso, las conmemoraciones prácticamente se solapaban, pues no habían terminado todos los actos relativos a las exequias del fallecido Felipe V cuando comenzaban ya los preparativos para exaltar la coronación de un nuevo rey. Todos estos actos tenían unos gastos desorbitados, pero no podemos olvidar que cumplían una labor vital en la cohesión de un imperio muy difícil de mantener unido. Más que en ningún otro caso, las imágenes se pusieron al servicio de la política para hacer valer sus poderes de raigambre ancestral. Toda la ciudad era revestida de telas, tapices y todo tipo de obras brillantes y coloristas. Como se señala en una de las relaciones, "nadie reservó cosa preciosa, con que pudiese resaltar el adorno de sus casas. Las mejores tapicerías, cortinas de tela, rasos de China, terciopelo, y damascos [...] ramos de flores artificiales, de plata o seda, en disposiciones caprichosas, aumentaban la hermosura». ${ }^{8}$ Las telas conferían color y alegría, los tapices recordaban victorias bélicas y hazañas del pasado, las miles de hachas repartidas por todos los lugares importantes iluminaban las noches prácticamente como si fuera de día; y en todos los lugares estratégicos, los retratos reales aparecían encabezando los túmulos, coronando los arcos, contemplando las masas desde los balcones municipales o recorriendo sus calles sobre lujosos carros.

El treinta de agosto y el uno de septiembre de 1746, se celebraron las exequias del difunto Borbón y, tan sólo dos meses después,

7. Un ejemplo de características similares lo encontramos en las figuras votivas de tamaño real habituales en algunas regiones de la Italia renacentista. Uno de los primero en acercarse a estos problemas fue Aby Warburg en su estudio sobre el arte del retrato y la burguesía florentina, donde analizaba estas figuras de cera que inundaban la iglesia de la Santissima Annunziata. Éstas eran elaboradas mayoritariamente por los Benintendi, discípulos de Verrocchio, los cuales tenían toda una fábrica dedicada a la confección de estas imágenes (Warburg, 2005: 151). Tal fue la fama de estos exvotos que pronto comenzó a faltar espacio en la iglesia y comenzaron a colgar las figuras sobre tirantes en un improvisado segundo piso. Esta macabra estampa no ha llegado hasta nuestros días, pero se conservan los testimonios de viajeros que describieron estas prácticas y, además, se sabe incluso que tuvieron que reforzarse los muros de la iglesia para poder sostener el peso de las efigies (Didi-Huberman, 1994: 415). Sin ir más lejos, las esculturas en oración perpetua de Carlos V y su familia que realizaran los Leoni para la Basílica de El Escorial mantienen en su esencia unas características muy similares a los ejemplares votivos italianos

8. Breve puntual descripcion de la magnifica, y plausible solemnidad, con que la mui Noble, y siempre Leal Ciudad deSevilla celebró el dia 6 de Noviembre de 1746 el Acto de levantar el Real Pendon por la Augusta, y Catholica Magestad del Rey nuestro Señor Don Fernando El Sexto, En Sevilla: en la imprenta de don Florencio Ioseph de Blàs y Quesada, f. 5. 
las principales casas de la ciudad mostraban ya los retratos de los nuevos monarcas (Morales, 2005: 4). Poco a poco se fueron sucediendo diversos actos y la exhibición de lujosas obras efímeras de todo tipo, como la construida por los gremios de la ciudad ante la fachada de las Casas Capitulares, cuya cúspide estaría coronada por las imágenes de ambos reyes. Durante la habitual segunda proclamación del rey en el Patio de Banderas del Alcázar hispalense, se levantó un gran tablado suntuosamente decorado y presidido por el retrato de Fernando VI (Morales, 2005: 4). Lo mismo ocurrirá en otras construcciones efímeras levantadas para tal efecto, en las cuales prácticamente siempre los retratos reales eran los encargados de presidir las inmensas y ricas máquinas.

En las relaciones podemos leer unos interesantes comentarios sobre cómo era percibida por los asistentes aquella proliferación de imágenes de los nuevos reyes. Los cronistas son contundentes al señalar que "muchos balcones tenían expuestos a la aclamación de la fidelidad, los retratos de nuestros reyes, cuyas copias ha multiplicado en tanto número la lealtad de estos ciudadanos, que se puede aseverar sin temeridad, no haber ejemplar en la historia española de reyes, cuyos retratos se hayan solicitado con más anhelo, se hayan mirado con más afecto, y con no sé qué de interior impulso, que se siente, y es superior a cualquiera explicación". ${ }^{9}$ Esta sinceridad nos muestra a la perfección el profundo sentimiento que sentían quienes contemplaban los retratos reales.

Otro testimonio fundamental de estos hechos son los grandes lienzos de Domingo Martínez y su taller, antes reseñados, que se conservan hoy en el Museo de Bellas Artes de Sevilla. Esta importante Máscara dio a su vez lugar a una relación publicada en la misma ciudad en 1751 con el título de Nuevo Mapa descripción iconológica del Mundo Abreviado, redactada por Don Ramón Cansino Casafonda (Morales, 2005: 8). ${ }^{10}$ Nos fijaremos ahora en la séptima pintura que representa la procesión del Carro del Parnaso [fig. 2]. Inician la cabalgata diversos personajes representando a los reinos y provincias de la Monarquía hispana, tras ellos avanza un grupo de músicos a caballo y después se observan unas figuras que simulan ser guardias de corps. Inmediatamente después caminan seis parejas de guardias con un alférez sosteniendo el pendón real, un caballero, un exempto real, seis caballos para arrastrar el carro con dos cocheros y cuatro lacayos vestidos de librea (Morales, 2005: 17). Como se puede observar, se ha cuidado al detalle la estampa para que se parezca al máximo a una verdadera comitiva real. Las vestimentas, el orden de los personajes, todo concuerda salvo el hecho de que no viajan los reyes sino sus retratos en el carro. Éstos iban acomodados en un trono con almohadones cubiertos por dosel y corona imperial, recibiendo el mismo tratamiento que si se trataran de las personas reales (fig. 2 y 3 ). Los retratos probablemente los pintara Juan de Espinal basándose en las pinturas que unos años antes había elaborado Jean Ranc en la corte Madrileña.

\section{PRESENCIAS VIRTUALES EN LOS RETRATOS DE LAS FIESTAS BARROCAS}

La problemática conceptual que presenta lo virtual, supera con creces la habitual tendencia reduccionista de oposición con lo real. ${ }^{11}$

9. Breve puntual descripcion de la magnifica, y plausible solemnidad, con que la mui Noble... f. 6.

10. Más información sobre esta relación y la interpretación iconográfica de sus emblemas en Pizarro Gómez, 2000: 477-493.

11. Aunque en algunos casos, el binomio real/virtual pueda ser suficiente según las argumentaciones que se quieran ofrecer, en nuestro caso precisa de una mayor atención. Ejemplo de esta tendencia simplificadora la encontra-

IMAGO, NÚM. 5, 2013, 7-I7 
Las aportaciones de importantes pensadores como Gilles Deleuze o Henri Bergson en torno a estas cuestiones nos ayudarán a explicar y comprender mejor el funcionamiento de estos retratos. A partir de Diferencia y repetición (Deleuze, 2002), Deleuze determina un nuevo paso en el estudio de los aspectos relativos a la virtualidad. Ya no es lo real lo que se contrapone a lo virtual, sino lo actual, y es que tanto lo actual como sus virtuales son siempre reales. Indudablemente la complejidad de las ideas expresadas en la monumental obra de Deleuze desbordan completamente los propósitos de este trabajo, por ello es preciso advertir que tan sólo nos valdremos de algunas de estas ideas para aplicarlas al argumento que venimos desarrollando. De hecho, tanto en Bergson como en Deleuze, la noción de lo virtual actúa en el contexto de unos problemas específicos y opera en una serie de capas diferentes. Por tanto, cabe señalar que hay muchas modalidades de lo virtual y éstas pueden funcionar en un rango de objetos muy amplio (Ansell Pearson, 2005: 1113). Para Deleuze, «el objeto virtual es un objeto parcial, no por el simple hecho de carecer de una parte que permanece en lo real, sino en sí mismo y por sí mismo, porque se escinde, se desdobla en dos partes virtuales, una de las cuales, siempre, falta a la otra. En pocas palabras, lo virtual no está sometido al carácter global que afecta los objetos reales. Es, no sólo por su origen, sino en su naturaleza propia, jirón, fragmento, despojo» (Deleuze, 2002: 160).

En una edición ampliada de los Diálogos de Deleuze con Claire Parnet, se recoge un texto hasta entonces inédito titulado Lo actual y lo virtual. ${ }^{12}$ En él, Deleuze recorre las principales claves que definen estos conceptos. Explica que «no hay objeto puramente actual [pues] todo actual se rodea de círculos de virtualidades siempre reno- vados [y además] las imágenes virtuales no se pueden separar del objeto actual ni éste de aquellas" (Deleuze y Parnet, 1996: 179180). El filósofo francés extiende estas consideraciones hacia matices y ramificaciones verdaderamente sugerentes que, si bien ahora no las atenderemos, es importante señalar que no han de perderse de vista para futuros acercamientos más profundos. Recurriendo a Bergson, Deleuze comenta que «el objeto real [actual] se refleja en una imagen en espejo como objeto virtual que, por su lado y simultáneamente, envuelve o refleja a lo real: hay 'coalescencia' entre ambos». De modo que la relación entre lo actual y lo virtual es como una «imagen de dos caras». Lo actual refleja una serie de virtuales que por su parte pueden cobrar vida y convertirse en actuales, sin perjuicio de que en cualquier momento vuelvan a desandar el camino, como en un círculo cerrado. Además, lo virtual convertido en actual puede a su vez generar nuevos virtuales describiendo así una configuración de círculos concéntricos.

Vistos -muy brevemente- los puntos claves de la relación actual/virtual, pasaremos a concretar su aplicación al ejemplo de los retratos festivos. En primer lugar, lo virtual de estos retratos no son otras imágenes-objeto como tal, sino las ideas que éstos manifiestan, sugieren, emanan o reflejan. Son ideas que tienen relación con su actual (recordemos el círculo cerrado), pero que, por otra parte, presentan una dimensión casi autónoma. El retrato del monarca es materialmente real (y también actual en sentido deleuzeniano) y al mismo tiempo expresa unas ideas virtuales, por ejemplo, de dignidad, fuerza, poder, o de la propia monarquía hispánica. Para el filósofo francés, «la imagen virtual absorbe toda la actualidad del personaje, al mismo tiempo que el personaje nada más es lo que es una

mos en el propio Mirzoeff, quien comenta: "por definición virtualidad es una imagen o un espacio que no es real pero parece serlo" (Mirzoeff, 2003: 91).

12. Se trata de un anexo expuesto como capítulo V. Deleuze y Parnet, 1996: 179-185. 
virtualidad» (Deleuze y Parnet, 1996: 184), es decir, el rey es realmente un monarca en las obras que lo representan como tal; en sí mismo (como persona física) carece de esa condición que sus retratos subrayan. Louis Marin llega a esta misma conclusión a pesar de no hacer referencia a Deleuze:

El retrato del rey que el rey contempla le ofrece el icono del monarca absoluto que él desea ser, al extremo de reconocerse e identificarse por él y en él en el momento mismo en que el referente del retrato se ausenta. El rey sólo es verdaderamente rey, es decir, monarca, en imágenes. Éstas son su presencia real: una creencia en la eficacia y la operatividad de sus signos icónicos es obligatoria, porque, de lo contrario, el monarca se vacía de toda su sustancia por falta de transustanciación y de él no queda sino el simulacro (Marin, 2009: 139).

Con estas palabras quizá debiéramos plantearnos el título de este artículo, ya que, como vemos, lo que en el fondo se manifiesta en estos retratos es la presencia real del monarca, pues en palabras de Deleuze, lo virtual es igualmente real. Recordando la frase de los lógicos de Port-Royal y aplicada a nuestro caso, el retrato de Fernando VI, es Fernando VI. Por un lado tenemos a la persona y por otro, valga el juego de palabras, la (re)presentación de lo que él representa, es decir, la presencia virtual de su idea (p. e. la monarquía). En el famoso estudio de Kantorowiczs sobre Los dos cuerpos del rey aparecen ya estas ideas desarrolladas, aunque con unos presupuestos diferentes que conviene tener en cuenta (Kantorowicz, 1985). El medievalista recoge algunos textos surgidos a la luz de los juicios sobre el Ducado de Lancaster durante el reinado de Isabel I (1533-1603) en los que se exponen las ideas de los juristas reales al respecto de los dos cuerpos del rey:
Que según el Common Law, ningún acto que el Rey realiza en su condición de Rey, podrá ser anulado por razón de su minoría de edad. Pues el Rey tiene en sí dos Cuerpos, v. gr., un Cuerpo natural, y un Cuerpo político. Su Cuerpo natural (considerado en sí mismo) es un Cuerpo mortal y está sujeto a todas las Dolencias que provienen de la Naturaleza y del Azar; a las Debilidades propias de la Infancia o la Vejez, todas aquellas Flaquezas a las que están expuestos los cuerpos naturales de los otro hombres. Pero su Cuerpo político es un Cuerpo invisible e intangible, formado por la Política y el Gobierno, y constituido para dirigir al Pueblo y para la Administración del bien común, y en este Cuerpo no cabe ni la Infancia ni la Vejez ni ningún otro Defecto ni Flaqueza natural a los que el Cuerpo natural está sujeto. ${ }^{13}$

Haciendo un arriesgado paralelismo entre ambas propuestas (Deleuze y Kantorowicz), el cuerpo natural sería el actual, es decir, el rey de carne y hueso (o en un segundo círculo concéntrico el retrato), y el cuerpo político se correspondería con sus virtuales, remitiendo a todo aquello que concierne al monarca como idea abstracta.

\section{ALGUNAS OBSERVACIONES A MODO DE CONCLUSIÓN}

Analizando lo hasta aquí expuesto, comprobamos que resulta difícil establecer una categorización (de orden teórico) fiable y sólida de los retratos reales. Por una parte vemos que éstos (los objetos físicos) reciben el tratamiento propio de un monarca, lo cual nos hace pensar que lo que en la imagen veían los asistentes a las fiestas era al propio rey (sin necesitar que éste fuera de carne y hueso). Marin explica que, en cierta medida, el retrato es la persona que representa ya que como decía el cronista André Félibien sobre el cuadro de Le Brun, éste es el rey.

13. Eduardo VI, predecesor de la reina, había cedido durante su minoría de edad unos territorios del Ducado de Lancaster, lo que provocó una posterior disputa legal. Cfr Kantorowicz, 1985: 19.

IMAGO, NÚM. 5, 2013, 7-I7 
En sus escritos, se observa que para Félibien, el sujeto es el rey y no un cuadro que le está representando (Marin, 1981: 253). Pero, por otra parte, además de esta consideración de realidad que vemos en este ejemplo, así como en los comentados sobre la exaltación al trono de Fernando VI, debemos añadir los comentarios al respecto de la virtualidad que han sido recogidos a partir de Deleuze. Una cosa es el tratamiento de realidad que se le da a un cuadro y otra cosa es el grado de actualidad que éste ostenta. Dicho tratamiento es motivado por los virtuales que emana la obra, los cuales, insertos dentro de un régimen escópico dado, actúan como detonantes de una apreciación metafísica de la misma. Marin resume acertadamente que "el misterio del retrato es el misterio de un sacramento 'político'" (Marin, 1981: 255).

Como se habrá podido comprobar, son muchos los flecos abiertos en este trabajo que no han podido ser solucionados ya que precisarían de un análisis más detenido. Evidentemente, más allá de la discusión teórica de dichas imágenes, cabría ponerlas en conexión con otras ideas fundamentales como la vigilancia, el control, el dominio, el poder, el aura, la mirada, etc., que esperamos poder desarrollar en futuras investigaciones.

\section{BIBLIOGRAFÍA}

Ansell Pearson, K. [2005]. "The reality of the Virtual: Bergson and Deleuze», $M L N$, vol. 120, $\mathrm{n}^{\circ}$ 5, 1112-1127.

BAL, M. [2004]. "El esencialismo visual y el objeto de los Estudios Visuales", Estudios Visuales, $\mathrm{n}^{\circ} 2$, diciembre 2004, 12-49.

BAzIN, A. [1967]. What is cinema?, London, University of California Press.

Belting, H. [2010]. Antropología de la imagen, Buenos Aires, Katz [Alemania, 2002].
BreA, J. L. [2006], «Estética, Historia del Arte, Estudios Visuales», Estudios Visuales, $\mathrm{n}^{\circ}$ 3, 8-26.

BreA, J. L. [2007]. "Cambio de régimen escópico: del inconsciente óptico a la $e$ image», Estudios Visuales, no 4, 146-163.

Corteguera, L. R. [2009]. "Talking Images in the Spanish Empire: Vision and Action", VisualResources, 25, 1, 53-68.<http://dx.doi. org/10.1080/01973760802674358>

Deleuze, G. [1996]. La imagen-tiempo. Estudios sobre cine 2, Barcelona, Paidós Comunicación [Francia, 1985].

Deleuze, G. [2002]. Diferencia y repetición, Buenos Aires, Amorrortu Editores [Francia, 1968].

Deleuze, G. y Parnet, C. [2008]. Dialogues, Paris, Flamarion, Champs Essais $\left[1^{a}\right.$ edic. 1996].

Didi-Huberman, G. [1994]. "Ressemblance mythifiée et resemblance oubliée chez Vasari", Melanges de l'École Française de Rome, 106, 383-432. <http://dx.doi. org/10.3406/mefr.1994.4334>

Didi-Huberman, G. [2008]. Ressemblance par contact. Archéologie, anachronisme et modernité de l'empreinte, Paris, Les Éditions de Minuit.

Didi-Huberman, G. [2009]. La imagen superviviente. Historia del arte y tiempo de los fantasmas según Aby Warburg, Madrid, Abada Editores.

Didi-Huberman, G. [2010a]. Ante la imagen. Pregunta formulada a los fines de una historia del arte, Murcia, Cendeac [París, 1990].

Didi-Huberman, G. [2010b]. Lo que vemos, lo que nos mira, Buenos Aires, Bordes Manantial [Francia, 1992].

FreedberG, D. [2009]. El poder de las imágenes. Estudios sobre la historia y la teoría de la respuesta, Madrid, Cátedra.

Kantorowicz, E. H. [1985]. Los dos cuerpos del rey. Un estudio de teología política medieval, Madrid, Alianza [Estados Unidos, 1957]. 
MARIN, L. [1975]. La critique du discours. Sur la «Logique de Port-Royal» et les "penses» de Pascal, Paris, Les Editions de Minuit.

MARIN, L. [1981]. Le portrait du roi, Paris, Les Editions de Minuit.

MARIN, L. [2009]. "Poder, representación, imagen», Prismas, Revista de historia intelectual, $\mathrm{n}^{\circ} 13,135-153$.

Mínguez, V. [2009]. «Imágenes jeroglíficas para un imperio en fiesta», Relaciones: Estudios de historia y sociedad, Vol. 30, $\mathrm{n}^{\mathrm{o}}$ $119,81-111$.

Mirzoeff, N. [2003]. An introduction to Visual Culture, Nueva York, Routledge [ $3^{\text {a }}$ reimpresión de la edición de 1999].

Mitchell, W.J.T. [2003]. "Mostrando el Ver: una crítica de la cultura visual», Estudios Visuales, $\mathrm{n}^{\circ}$ 1 17-40.

Morales, A. J. [2005]. "Imagen urbana y fiesta pública en Sevilla: la exaltación al trono de Fernando VI", Reales Sitios, $n^{\circ}$ 165 , 3er trimestre.

NANCY, J.L. [2006]. La mirada del retrato, Buenos Aires, Amorrortu editores [Francia, 2000].
Panzanelli, R. [2008]. "Compelling Presence. Wax Effigies in Renaissance Florence», en Ephemeral Bodies: Wax Sculpture and the Human Figure, Los Angeles, Getty Research Institute.

Pizarro Gómez, F. J. y Viña Díaz, S. [2000]. "La Máscara del mundo abreviado de Sevilla. Iconografía y emblemática en la fiesta urbana del siglo XVIII», en M. Torrione (ed.), España Festejante. EL siglo XVIII, Málaga, 477-493.

Puelles Romero, L. [2011]. Mirar al que mira, Madrid, Abada Editores.

R. DE LA FLOR, F. [2009]. Imago. La cultura visual y figurativa del barroco, Madrid, Abada Editores.

WARBURG, A. [2005]. "El arte del retrato y la burguesía florentina. Domenico Ghirlandaio en Santa Trinità. Los retratos de Lorenzo de Medici y su familia», en El renacimiento del paganismo: Aportaciones a la historia cultural del Renacimiento Europeo, Madrid, Alianza Editorial [ $1^{a}$ edición, Alemania, 1932, artículo escrito en 1902]. 